\title{
THE IMPACT OF RAMAZAN I'TIKAF ON IMMUNE SYSTEM
}

\author{
Hasan Huseyin Eker ${ }^{1}$, Mehmet Derya Onuk ${ }^{2}$, Caglayan Geredeli ${ }^{3}$ and Maihebureti Abuduli ${ }^{1}$ \\ ${ }^{1}$ Department of Public Health, Faculty of Medicine, University of Health Sciences, Istanbul, Turkey \\ 'University of Health Sciences Fatih Sultan Mehmet Teaching and Research Hospitallstanbul, Turkey \\ ${ }^{3}$ University of Health Sciences Okmeydanı Teaching and Research Hospital Istanbul, Turkey
}

Corresponding author:

Hasan HuseyinEker

Email: hheker@yahoo.com

\begin{abstract}
I'tikaaf is a worship maintained by very deep hunger in fasting month of Ramadan. Hunger causes different results on the immune system. This is a prospective study. In this study, the changes in the immune system were investigated during the period of the i'tikaf, which is deep hunger worship. In the last 10 days of Ramadan, before and at the end of $i$ 'tikaf blood was taken from 46 male volunteers who performed i'tikaf worship and various biochemical and immunological parameters were examined. Comparison of the measures taken before and after i'tikaf indicated a statistically significant decrease in weight, BMI, waist circumference and hip circumference $(p<0.001)$. Of the hematologic parameters, the lymphocyte count increased significantly $(p=0.009)$. Also, a significant increase was observed in the values of $\lg A$, IgM ve $\lg G$ within the hematological parameters $(p<0.001)$. During the period of i'tikaf, feeding with very low calories (1000 calories) caused an increase in the levels of lymphocyte and immunoglobulins and got the immune system stronger.
\end{abstract}

Keywords: Immune system, Ramadan l'tikaf, weight, BMI, immune system.

\section{INTRODUCTION}

Each year Muslims all over the world observe the annual fast for either 29 or 30days, changing from year to year, using the lunar calendar (every year corresponds to 10 days before the Gregorian calendar). Fasting is a worship, Muslims refrain from consuming food, drinking liquids, smoking, and engaging in sexual relationsstarting from pre-dawn time till sunset. As the times of sunset changes throughout the year, this period of time requires staying hungry and thirsty for shorter time such as 11-12 hours in the months with short daytime and longer time such as 17-18 hours and even more in months with long daytime 1 . Also, some Muslims carry out the worship of i'tikaf in conjunction with fasting in Ramadan.

According to Islamic belief, retreating somewhere and occupying oneself only with worship is called i'tikaf. Especially in the last 10 days of Ramadan, staying in mosques or similar places and being busy with worships such as worshiping, science of faith, Quran, prayers and dhikr. The legitimacy of i'tikaf is set with Quran and the sunnah of Islamicprophet ${ }^{2,3}$.

How fasting during Ramadan influenced people's vital functions was investigated through various studies? Fasting has been shown to be beneficial in some allergic and inflammatory diseases, in which the cause was considered to be associated with the immunological system ${ }^{4,5,6}$. Also, similar to the worship of i'tikaf in fasting month, the different responses of immune system to very low calories were investigated ${ }^{7}$. However, in some studies, it is thought that the limitation of total calory intake weakens immune system ${ }^{8}$. It was observed that the immune system of malnourished people and elderly people weakened and therefore the elder people easily caught infections that required hospitalization ${ }^{9}$. On the contrary, some recently published studies stated that shock fasting for more than 3 days could get the immune system stronger ${ }^{10}$.

Lymphocytes are the leading parameters that constitute the immune system. Lymphocytes and their products, constitute the most important part of cellular and humoral components of immune system ${ }^{11}$.Lymphocytes are primarily divided into 3 groups as Tcells, B cells and NK (Natural Killer) cells. For the generation and maintenance of normal immune response, there should be a balance between the lymphocyte subgroups with effector functions.

$\mathrm{T}$ cells carry out their regulator and effector functions via the substances called lymphokine. Lymphokines, unlike to antibodies, do not bind to antigens specifically, they play role in the regulation of cell functions. T helper lymphocytes carry the surface antigen of CD4 while suppressor and cyctotoxic $T$ cells carry the surface antigen of CD8. CD3 antigens are found in both $T$ helper and cytotocxic T cells. These CD3 antigens, found in 
both $\mathrm{T}$ helper and cytotoxic $\mathrm{T}$ cells are associated with signal transmission.

Natural Killer (NK) cells are the lymphocytes which bind to virally infected cells and some tumor cells and kill them by means of the cytotoxins that they release. These cells are found in bone marrow and spleen. Their cytotoxic activities are not antibody dependent. In some studies, increased cytolytic activity of NK lymphocytes against tumor cellswas observed in acute starvation. The reason of this activity is still unknown ${ }^{12,13,14}$. Recently, it was seen that the ratio of neutrophil-lymphocyte is also an indicator in immunity and cancer patients with high ratios of platelet-lymphocyte and neutrophillymphocyte had worse prognosis ${ }^{15,16}$. Aim of the study was to investigate how immune system changes during the period of i'tikaf which contains feeding with very low calories in Ramadan.

\section{MATERIALS AND METHODS}

A prospective study carried out in this study and it was conducted between the dates of 24.06.2016 and 01.07.2016, between the 20th and 27th days of Ramadan. In this study, male participants who performed i'tikaf in the way of seclusion in the cities of Istanbul and Denizli were included. I'tikaf can be performed via many other ways. The i'tikaf with the way of seclusion consists of a portion of unsalted, low-fat lentil soup (200g) and $150 \mathrm{~g}$ bread in the evening meal and 21 dried grapesand $150 \mathrm{~g}$ bread in sahur to be eaten. The daily calorie intake in total is approximately 1000 calories.

The participants were informed about the study and an informed consent was taken from the volunteers. In total 46 volunteers participated in the study. As lightly dressed and without shoes, the weight, height, waist circumference, hip circumference of all subjects participated the study were measured and BMI was calculated.BMI was calculated as $\mathrm{kg} /$ height $(\mathrm{m})$. Before and after i'tikaf, the blood samples were taken by going go the mosque that the participants were retreated in. The samples were brought to the Central Laboratory of Bezmialem Foundation University, Faculty of Medicine within appropriate storage boxes $(+4 C)$. In blood sample analysis, the levels of IgA, IgM, IgG, which are indicators of humoral immunity, and P1, CD19, CD3, CD3 Helper, CD3 cytotoxic, CD3, NKT, NK cell, CD3 HLA DR1, CD3 HLA DR2 values which are another indicator of immune system were measured by flow cytometry. The values before and after i'tikaf were statistically compared.

All calculations were done using the SPSS v. 11.5 statistical software package (the system for statistics) for analysis of the data. All data were expressed as meanstandard deviation (SD). Comparisons between means observed before and after i'tikaf were tested using a paired t-test. The data within each phase were also examined using Pearson $r$ correlation analysis to find the relationship between the studied variables. All differences were considered to be significant at $p<0.05$.

\section{RESULTS}

Forty-six healthy male volunteers participated and Chi-scare student test used in the study. The mean age of the participants was 41 years. Of the parameters measured before and after i'tikaf, weight, waist circumference, hip circumference and BMI decreased significantly (Table 1). A statistically significant increase was noted in the lymphocyte count, one of the hematological parameters $(p=0.009)$. The monocyte count which is another hematologic parameter was observed to be increased but the increase did not reach the level of statistical significance $(p=0.07)$. The neutrophil count, another hematologic parameter, did not change significantly $(p=0.60)$. There was a statistically significant increase in the indicators of humoral immunity which are $\lg A, \lg M, \lg G(p<0.001$, $p<0.001, p=0.03$, respectively) (Table-1). P1, CD19, CD3, CD3 Helper, CD3 cytotoxic, CD3 NK cell, CD3 HLA DR1, CD3 HLA DR2 which are another indicator of immune system response were assayed with flowcytometry. Although a minimal decrease was observed after i'tikaf, it was not statistically significant. There was a minimal but statistically insignificant increase in NKT cells after i'tikaf. 
Table 1. Differences before and after l'tikaf

\begin{tabular}{|c|c|c|c|c|}
\hline Parameters & Before i'tıkaf & After i'tıkaf & Difference & $P$ value \\
\hline Weight & $81,19+12,65$ & $79.08+12,56$ & $2,11+1,3$ & $0,00^{* * *}$ \\
\hline BMI & 26.7 & 26.0 & 0.7 & $0.00^{* * *}$ \\
\hline $\begin{array}{l}\text { Waist } \\
\text { circumference }(\mathrm{cm})\end{array}$ & 95.5 & 93.0 & 2.5 & $0.00^{* * *}$ \\
\hline $\begin{array}{l}\text { Hip } \\
\text { circumference }(\mathrm{cm})\end{array}$ & 106.8 & 104.4 & 2.4 & $0.00^{* * *}$ \\
\hline WBC & 6.00 & 5.99 & 0.01 & 0.96 \\
\hline Neutrophil & 3.02 & 2.95 & 0.07 & 0.60 \\
\hline Lymphocyte & 2.12 & 2.56 & -0.44 & $0.009^{* *}$ \\
\hline Monocyte & 0.49 & 0.54 & -0.05 & 0.07 \\
\hline Platelet & 223 & 227 & -4.43 & 0.23 \\
\hline All events & 1.72 & 1.53 & 0.19 & $0.00^{* * *}$ \\
\hline P1 & 5.54 & 5.25 & 0.29 & 0.29 \\
\hline CD 19 & 6.35 & 5.51 & 0.86 & 0.053 \\
\hline CD 3 & 4.10 & 3.87 & 0.23 & 0.27 \\
\hline CD 3 Helper & 2.29 & 2.11 & 0.18 & 0.12 \\
\hline CD 3 cytotoxic & 1.57 & 1.48 & 0.09 & 0.26 \\
\hline CD 3 NK cell & 7.70 & 7.60 & 0.10 & 0.84 \\
\hline NKT & 3.89 & 4.23 & -0.34 & 0.18 \\
\hline CD 3 HLADR 1 & 7.80 & 7.11 & 0.69 & 0.16 \\
\hline CD 3 HLADR2 & 6.21 & 6.49 & -0.28 & 0.41 \\
\hline MPV & 7.73 & 8.52 & -0.79 & $0.00^{* * *}$ \\
\hline NLR & 1.73 & 1.21 & 0.52 & 0.11 \\
\hline MLR & 0.26 & 0.22 & 0.04 & 0.27 \\
\hline TLR & 1.25 & 0.91 & 0.34 & 0.10 \\
\hline $\lg \mathrm{A}$ & 2.40 & 2.68 & -0.27 & $0.00^{* * *}$ \\
\hline $\lg M$ & 8.40 & 9.79 & -1.38 & $0.00^{* * *}$ \\
\hline $\lg \mathbf{G}$ & 1.15 & 1.22 & -0.68 & $0.03^{*}$ \\
\hline
\end{tabular}

${ }^{*}$ significant at $p<0.05,{ }^{* *}$ significant at $p<0.01,{ }^{* * *}$ significant at $p<0.001$

\section{DISCUSSION}

In our study when the situations before and after i'tikaf were compared, a reduction occurred in weight, BMI, waist and hip circumference in healthy volunteers. These results were similar to the results of the studies conducted on Ramadan fasting 17, 18, $19,20,21,22,23$.

The comparison of immunological parameters before and after i'tikaf did not result in a statistically significant change in the values of neutrophil and monocyte. But a statistically significant increase was detected in the rate of lymphocyte. The finding is accepted as an indicator of cellular immunity. The increase in the ratios of $M L, N L, P L$ was regarded as a bad prognostic sign in cancer patients ${ }^{24,25}$. However, in our study, despite being insignificant, the ratios of $\mathrm{NL}, \mathrm{ML}$ and $\mathrm{PL}$ were decreased and this condition drew the conclusion that i'tikaf has benefical effects on immune system.

In our study after i'tikaf, a statistically significant increase was observed in the levels of $\lg \mathrm{A}, \lg \mathrm{M}$ and IgG. Although a very few studies addressed these issues, in another study, the levels of immunoglobulins showed an increase in like manner to our study ${ }^{26}$ and formed the opinion that i'tikaf (short term deep hunger) affects the humoral immunity positively.

Although an increase was noted in natural killer T lymphocytes which are an indicator of cellular immunity, statistical significance was not reached. Despite the fact that there are very few studies on this subject, in both previous and recent studies, a strengthened immunity was detected after very deep hunger lasting more than 72 hours ${ }^{12,8}$. Our results are also in the direction that the immune system got stronger during the period of i'tikaf, which requires a very deep hunger.

The studies by Murray in Nigeria in 1973 and in Ethiopia in 1975 detected that the incidence of the diseases like tuberculosis, malaria and brucellosis was lower in the victims striving on starvation in Ethiopia and Nigeria, but their incidence increased after the victims were placed to the camping areas and started to feed ${ }^{27,28,29}$. The results of our study also suggest that immunity gets stronger with fasting. 


\section{CONCLUSION}

According to the results of this study, i'tikaf (short term deep hunger) has decreased in weight, BMI. It has beneficial effects on immune system and immune system got stronger during the period of i'tikaf. The results of this study should be interpreted considering the limitations of this study. The results of this study cannot be generalized to all the people who have done i'tikaf due to small sample size, more clinical studies are needed.

\section{ACKNOWLEDGEMENT}

Authors are much thankful to all the participated in the study. The authors also grateful to Bezmialem University for giving the approval to conduct this study in their facility.

\section{REFERENCES}

1. Waterhouse J, Alkib L, Reilly T(2008). Effects of Ramadan upon fluid and food intake, fatigue, and physical, mental, and social activities: a comparison between the UK and Libya. Chronobiol Int . 25: 697-724.

2. A'râf: 7/138; Tâhâ: 20/91, 97; Enbiyâ: 21/52; Şuarâ: 26/71; Fetih: 48/25.

3. Buhârî, “i'tikâf”, 1, 6,17, “hayz", 303, "ezan", 629; Müslim, “i'tikâf”, 1-4, "zekat", 1031; Ebû Dâvud, "Savm", 77, 2476, 78; Tirmizî, "Savm", 71, "zühd”, 2391; ỉbn Mâce, “Mukaddime”, 210, "Siyâm", 58,1780; Ebû Dâvud, "Savm", 77,79, 2476; Taberânî, “Mu'cemu'l-Kebîr”; "Mecmau'z-Zevâid”, III,173; Darimi, "Taharet”, 877; Nesai, “Âdabu'l-Kudat”, 5380;Malik, "el-Cami", 1777; Ahmed, 6/131, 2/439.

4. Kieldsen-

Kragh J, Haugen M, Borchgrevink CF, et al. (1991). Controlled trial of fasting and one-year vegetarian diet in rheumatoid arthritis. Lancet. 338: 899-902.

5. Mohammed KIA, Mahmood MM (2010).

Effect of Ramadan fasting on the levels of IL-1a, IL-2, IL-6 and IL-8 cytokines. Diyala J Pure Sci. 6: 308-313.

6. Rouhani MH \& Azadbakht L(2014). Is Ramadan fasting related to health outcomes? A review on the related evidence. J Res Med Sciv.19 (10).

7. Shcherbakov VI, Pozdnyakov IM (2004). Study of some immunity parameters in patients receiving low-caloric diets. Bull Exp Biol Med.138: 565-567.

8. Wardwell L, Chapman-

Novakofski K, Herrel S, et al. (2008). Nutrient intake and immune function of elderly subjects. J Am Diet Assoc. 108: 2005-2012.

9. Walrand S, Moreau K, Caldefie F, et al. (2001). Specific and nonspecific immune responses to fasting and refeeding differ in healthy young adult and elderly persons. Am J Clin Nutr.74: 670-678.

10. Tanya B. Dorff, Susan Groshen, Agustin Garcia, Manali Shah, Denice Tsao-Wei, Huyen Pham, Chia-Wei Cheng, Sebastian Brandhorst, Pinchas Cohen, Min Wei, Valter Longo, and David I (2016). QuinnSafety and feasibility of fasting in combination with platinum-based chemotherapy.BMC Cancer.16: 360.

11. Philip C. Calder(2007), Immunological Parameters: What Do They Mean?J. Nutr. 137: 773S-780S.

12. Dang VT, Tanabe K, Tanaka $\mathrm{Y}$, Tokumoto $\mathrm{N}$, Misumi T, Saeki Y, Fujikuni N, Ohdan H (2014). Fasting enhances TRAIL-mediated liver natural killer cell activity via HSP70 upregulationPLoS One. 30;9(10).

13. Wing EJ, Stanko RT, Winkelstein A, Adibi SA (1983). Fasting-enhanced immune effector mechanisms in obese subjects. Am $\mathrm{J}$ Med. 75(1):91-6.

14. Saxena RK, Saxena QB, Adler WH (1980). Regulation of natural killer activity in vivo: Part l--loss of natural killer activity during starvation.Indian $J$ Exp Biol. 18(12):1383-6.

15. Ann Surg Oncol. Yodying $H$, Matsuda A, Miyashita M, Matsumoto S, Sakurazawa N, Yamada M, Uchida E (2016).Prognostic Significance of Neutrophil-toLymphocyte Ratio and Platelet-toLymphocyte Ratio in Oncologic Outcomes of Esophageal Cancer: A Systematic Review and Meta-analysis.Ann SurgOncol.23(2):646-54.

16. Wu Y, Li C, Zhao J, Yang L, Liu F, Zheng H, Wang Z, Xu Y(2016). Neutrophil-tolymphocyte and platelet-tolymphocyte ratios predict chemotherapy outcomes and prognosis in patients with 
colorectal cancer and synchronous liver metastasis. World J Surg Oncol. 16;14(1):289.

17. Fahrial Syam A,Suryani Sobur C,Abdullah M,Makmun (2016). Ramadan Fasting Decreases Body Fa $\mathrm{t}$ but Not Protein Mass.Int J Endocrinol Metab. 2;14(1).

18. Sadeghirad B, Motaghipisheh S, Kolahdooz F, Zahedi MJ, Haghdoost AA (2014). Islamic fasting and weight loss: systematic review and meta-analysis.Public Health Nutr. 17(2):396-406.

19. M Haouari , F Haouari-Oukerro , A Sfaxi et al. (2008) How Ramadan fasting affects caloric consumption, body weight, and circadian evolution of cortisol serum levels in young, healthy male volunteers. Horm Metab Res. 40:575-577.

20. Hajek P1, Myers K, Dhanji AR, West $O$, McRobbie $H(2012)$ Weight change during and after Ramadan fasting. J Public Health (Oxf). 34, 377-381.

21. Norouzy A, Salehi M, Philippou E, Arabi $\mathrm{H}$, Shiva F, Mehrnoosh S, Mohajeri SM, Mohajeri SA, Motaghedi Larijani A, Nematy M (2013). Effect of fasting in Ramadan on body composition and nutritional intake: a prospective study.J Hum Nutr Diet. 1:97-104.

22. Pichler M, Hutterer GC, Stoeckigt C, et al. (2013). Validation of the pre-treatment neutrophil-lymphocyte ratio as a prognostic factor in a large European cohort of renal cell carcinoma patients. $\mathrm{Br} J$ Cancer. 108:901-907.

23. Templeton AJ, Ace 0, McNamara MG, et al. 2014. Prognostic role of platelet to lymphocyte ratio in solid tumors: a systematic review and meta-analysis. Cancer Epidemiol Biomarkers Prev. 23:1204-1212.

24. Shi L, Qin $X$, Wang $H$, Xia $Y$, Li $Y$, Chen $X$, Shang L, Tai YT, Feng $X$, Acharya $P$, Acharya C, Xu Y, Deng S, Hao M, Zou D, Zhao Y, Ru K, Qiu L, An G (2016). Elevated neutrophilto-lymphocyte ratio and monocyte-tolymphocyte ratio and decreased plateletto-lymphocyte ratio are associated with poor prognosis in multiple myeloma.Oncotarget. $12 . \quad$ doi: 10.18632/oncotarget.13320.
25. Badora-Rybicka A, Nowara E, StarzycznyStota D(2016). Neutrophil-tolymphocyte ratio and platelet-tolymphocyte ratio before chemotherapy as potential prognostic factors in patients with newly diagnosed epithelial ovarian cancer.BMJ. ESMO Open.1(2):e000039.

26. Develioglu ON, Kucur M, Ipek HD, Celebi S, Can G, Kulekci M (2013). Effects of Ramadan fasting on serum immunoglobulin $G$ and $M$, and salivary immunoglobulin A concentrations.J Int Med Res. 41(2):463-72.

27. Murray MJ, Murray NJ, Murray AB, et al. (1976). Refeeding-malaria and hyperferremia. Lancet 1975; I: 653-654.

28. Murray MJ, Murray MB, Murray $A B$, et al. (1976). Somali food shelter in the Ogaden famine and their impact on health. Lancet. I: 1283-1285.

29. Murray J, Murray A (1977). Suppression of infection by famine and its activation by refeeding-a paradox?. Perspect Biol Med. 7977; 20: 477-483. 